\title{
Ayurvedic medicinal plants for Alzheimer's disease: a review
}

\author{
Rammohan V Rao*1, Olivier Descamps', Varghese John ${ }^{1}$ and Dale E Bredesen ${ }^{\dagger 1,2}$
}

\begin{abstract}
Alzheimer's disease is an age-associated, irreversible, progressive neurodegenerative disease that is characterized by severe memory loss, unusual behavior, personality changes, and a decline in cognitive function. No cure for Alzheimer's exists, and the drugs currently available to treat the disease have limited effectiveness. It is believed that therapeutic intervention that could postpone the onset or progression of Alzheimer's disease would dramatically reduce the number of cases in the next 50 years. Ayurvedic medicinal plants have been the single most productive source of leads for the development of drugs, and over a hundred new products are already in clinical development. Indeed, several scientific studies have described the use of various Ayurvedic medicinal plants and their constituents for treatment of Alzheimer's disease. Although the exact mechanism of their action is still not clear, phytochemical studies of the different parts of the plants have shown the presence of many valuable compounds, such as lignans, flavonoids, tannins, polyphenols, triterpenes, sterols, and alkaloids, that show a wide spectrum of pharmacological activities, including anti-inflammatory, anti-amyloidogenic, anticholinesterase, hypolipidemic, and antioxidant effects. This review gathers research on various medicinal plants that have shown promise in reversing the Alzheimer's disease pathology. The report summarizes information concerning the phytochemistry, biological, and cellular activities and clinical applications of these various plants in order to provide sufficient baseline information that could be used in drug discovery campaigns and development process, thereby providing new functional leads for Alzheimer's disease.
\end{abstract}

\footnotetext{
*Correspondence: rrao@buckinstitute.org

tSenior co-authors

'The Buck Institute for Research on Aging, 8001 Redwood Boulevard, Novato, CA 94945, USA

Full list of author information is available at the end of the article
}

\section{Introduction}

Alzheimer's disease (AD) is a progressive inexorable loss of cognitive function associated with the presence of senile plaques in the hippocampal area of the brain. The disease is the most common form of dementing illness among middle-aged and older adults, affecting more than 5 million Americans, a number estimated to increase to 7.7 million by 2030. Symptoms typically appear after age 60 , and some early-onset forms of the disease are linked to a specific genetic defect. Although the etiology is unknown, genetic factors clearly play a role in $10 \%$ to $15 \%$ of cases [1]. So far, efforts to find a cure for AD have been disappointing, and the drugs currently available to treat the disease address only its symptoms and with limited effectiveness. The underlying pathogenesis is a loss of neurons in the hippocampus, cortex, and subcortical structures [2]. Early disease shows a loss of short-term memory, inability to learn new information, mood swings, difficulty in finding words, forgetting names, and losing items. Frustration, hostility, and irritability are common emotional features exhibited by patients with $\mathrm{AD}$. In severe cases, patients become totally incontinent, memory is completely lost, and sense of time and place disappears. Patients become totally dependent upon others and eventually require comprehensive care. Owing to the patient's total dependency upon others, placement in a nursing home with full-time nursing care becomes necessary. Thus, AD presents a considerable problem in patient management as well. It is believed that therapeutic intervention that could postpone the onset or progression of $\mathrm{AD}$ would dramatically reduce the number of cases in the next 50 years [1].

Herbal medicine offers several options to modify the progress and symptoms of AD. There has been a new trend in the preparation and marketing of drugs based on medicinal plants, and their scientific and commercial significance appears to be gathering momentum in health-relevant areas. These plant-derived products are carefully standardized, and their efficacy and safety for a specific application have been demonstrated [3-7].

Ayurvedic medicine is a system of traditional medicine native to India, and Ayurvedic practitioners have developed a number of medicinal preparations and 
surgical procedures for the treatment of various ailments. An entire body of literature in the Ayurvedic texts deals with the nervous system and disorders associated with it. Nervous system disorders, called 'VataVyadhi' in Sanskrit, were thought to be brought on by imbalances of Vata, the biological air humor, the energy that moves through the brain and the nerves (the ancients considered nerve impulses to be a kind of wind or air traveling through the body) controlling both voluntary and involuntary functions. Hence, Vata derangements always involve some weakness, disturbance, or hypersensitivity of the nervous system. Included in these texts are direct references to age-associated memory loss, preventive care, and therapeutic interventions. These texts explain the use of several herbs and their qualities and energetics for nervous system disorders, including memory loss typically seen in older adults, but only recently have there been mechanistic studies on the role of these herbs in nervous system disorders and dementias, including dementia associated with $\mathrm{AD}$ [8]. Indeed, several scientific studies have described the use of various Ayurvedic medicinal plants termed 'nervines' and their constituents to strengthen the functional activity of the nervous system and restoration of memory $[8,9]$. Phytochemical studies have shown the presence of many valuable compounds, such as lignans, flavonoids, tannins, polyphenols, triterpenes, sterols, and alkaloids, that show a wide spectrum of pharmacological activities, including anti-inflammatory, anti-amyloidogenic, anti-cholinesterase, hypolipidemic, and antioxidant effects [5-8,10].

The present review puts together research on various Ayurvedic medicinal plants that have shown promise in reversing the $\mathrm{AD}$ pathology. The report summarizes information concerning the phytochemical, biological, and cellular activities and clinical applications of these various plants in order to provide sufficient baseline information that could be used in drug discovery campaigns and development processes, thereby providing new functional leads for AD. Below we describe the various Ayurvedic medicinal nervine herbs that are recommended for $\mathrm{AD}$ and their actions on the brain.

\section{Ashwagandha (Withania somnifera)}

Ashwagandha is used extensively in Ayurveda as a nervine tonic, aphrodisiac, and 'adaptogen' and helps the body adapt to stress $[9,11]$. Ashwagandha is a member of the nightshade (Solanaceae) family, and the root is the part that is widely used. It is categorized as a rasayana (rejuvenative) and is believed to possess antioxidant activity, free radical scavenging activity, and an ability to support a healthy immune system [12]. Unlike other adaptogens, which tend to be stimulating, Ashwagandha has a calming effect and thus may be particularly indicated in people with AD [13]. A total alkaloid extract of
Ashwagandha root exhibited a calming effect on the central nervous system (CNS) in several mammalian species, suggesting the use of this herb to produce relaxation. A recent double-blind, randomized, placebocontrolled study of the effects of Ashwagandha on stress found that it reduced symptoms of stress and inability to concentrate and reversed forgetfulness in a dose-dependent manner, and $500 \mathrm{mg} /$ day was more effective [14]. No additional adverse effects were found.

Ashwagandha contains steroidal compounds of great interest to researchers, such as the ergostane-type steroidal lactones, including withanolides A to $\mathrm{Y}$, dehydrowithanolide $\mathrm{R}$, withasomniferin $\mathrm{A}$, withasomidienone, withasomniferols $\mathrm{A}$ to $\mathrm{C}$, withaferin $\mathrm{A}$, and withanone. Other constituents include the phytosterols sitoindosides VII to $\mathrm{X}$ and beta-sitosterol as well as alkaloids (for example, ashwagandhine, cuscohygrine, tropine, pseudotropine, isopelletierine, and anaferine), a variety of amino acids (including tryptophan), and high amounts of iron $[9,15]$. A subset of these components (withanamides) has been shown to scavenge free radicals generated during the initiation and progression of $\mathrm{AD}$. Neuronal cell death triggered by amyloid plaques was also blocked by withanamides [13,16-18]. Molecular modeling studies showed that withanamides $\mathrm{A}$ and $\mathrm{C}$ uniquely bind to the active motif of beta-amyloid (A $\beta$ 25-35) and prevent fibril formation $[17,19]$. In the CNS, Ashwagandha has been reported to increase memory and learning [20]. Aqueous extracts of this herb have been found to increase cholinergic activity, including increases in the acetylcholine content and cholineacetyl transferase activity in rats and this might partly explain the cognition-enhancing and memory-improving effects $[21,22]$. In addition, recent reports have provided exciting information on the ability of this herb to stimulate neurite outgrowth [23]. Treatment with the methanol extract of Ashwagandha caused neurite outgrowth in a dose- and time-dependent manner in human neuroblastoma cells [21,24]. The levels of two dendritic markers, MAP2 and PSD-95, were found to be markedly increased in cells treated with Ashwagandha, suggesting that it stimulates dendrite formation [21,24]. In an extension of the above study, the same research group treated cultured rat cortical neurons with amyloid peptide that induced axonal and dendritic atrophy and loss of pre- and postsynaptic stimuli. Subsequent treatment with a methanol extract of Ashwagandha induced significant regeneration of both axons and dendrites. In addition to the reconstruction of pre- and postsynapses in the neurons, methanol extracts of Ashwagandha reversed amyloid peptide-induced memory deficit in mice [24]. These in vivo effects of Ashwagandha were maintained even after the discontinuance of the drug administration. Similarly, preliminary studies from this 
laboratory revealed significant neurogenesis in the dentate gyrus region only in J20 mice - mice that express the mutant form of human amyloid precursor protein (APP) bearing both the Swedish (K670N/M671L) and the Indiana (V717F) mutations - that were fed a diet containing the whole herb (Ashwagandha root powder, $2.5 \mathrm{~g} / \mathrm{kg}$ body weight) in comparison with J20 mice that received only normal chow (unpublished data). Although the data mentioned above are quite promising for the use of Ashwagandha as an anti-AD agent, additional clinical trials need to be conducted to support its therapeutic use. While the herb has been used successfully in Ayurvedic medicine for centuries, a systematic study of the acute or chronic toxicity of this herb or its various components is still lacking and additional studies are warranted to confirm the therapeutic significance of this herb [9].

\section{Note added in proof}

While the manuscript of this review was in the review process, Sehgal et al. (Proc Natl Acad Sci U S A 2012, 109:3510-3515) reported that oral administration of a semipurified extract of the Ashwagandha (W. somnifera) root reversed behavioral deficits, plaque load, and accumulation of beta-amyloid peptides in mouse models of AD. This therapeutic effect of W. somnifera was mediated through upregulation of liver low-density lipoprotein (LDL) receptor-related protein (LRP).

\section{Turmeric (Curcuma longa)}

Turmeric is a rhizomatous herbaceous perennial plant of the ginger family, Zingiberaceae. Derived from the rhizome and root, turmeric is used as a spice and coloring agent and in traditional medicine in Asia. The active constituents are thought to be turmerone oil and watersoluble curcuminoids, including curcumin [25]. Curcumin is the principal curcuminoid and is responsible for the yellow color of the turmeric root [25-27]. Turmeric is anti-inflammatory, antiseptic, and antibacterial and has long been used in the Indian system of medicine to treat a variety of conditions. This versatile spice helps detoxify the liver, balance cholesterol levels, fight allergies, stimulate digestion, and boost immunity [28]. Epidemiologic studies show a 4.4-fold lower incidence of $\mathrm{AD}$ in Southeast Asian countries where turmeric is commonly used as a dietary spice [29]. Other studies indicate that the non-steroidal anti-inflammatory property of turmeric is associated with a reduced risk of AD [30]. Indeed, when fed to aged mice with advanced plaque deposits similar to those of $\mathrm{AD}$, curcumin reduced the amount of plaque deposition [27,31-33]. It reduced oxidative damage and reversed the amyloid pathology in an AD transgenic mouse [32,33]. Direct injection of curcumin into the brains of the mice with $\mathrm{AD}$ not only hampered further development of plaque but also reduced the plaque levels [33]. AD symptoms characterized by inflammation and oxidation were also eased by curcumin's powerful antioxidant and anti-inflammatory properties [33]. In addition, a low dose of turmeric (160 parts per million, or ppm) reduced proinflammatory cytokine levels that are linked to the neuroinflammatory cascades involved in neuritic plaque pathogenesis [32]. Curcumin's in vitro ability to inhibit lipid peroxidation and neutralize reactive oxygen species may be several times more potent than that of vitamin E [34]. Toxicity studies were conducted by the National Cancer Institute by administering turmeric oleoresin (organic extract of turmeric) in feed to groups of male and female rats and mice for 13 weeks and 2 years. There were no acute or chronic clinical findings related to toxicity in either rats or mice receiving 2,000, 10,000 , or 50,000 ppm of turmeric oleoresin [35].

Owing to the promising findings in animal models, clinical trials of oral curcumin supplementation in patients with early AD are already under way [10,36]. In addition, the results of a six-month randomized, placebocontrolled, double-blind, clinical trial of curcumin in 27 patients with $\mathrm{AD}$ found that oral supplementation with up to $4 \mathrm{~g}$ /day of curcumin was safe [37]. Larger controlled trials are needed to determine whether oral curcumin supplementation is efficacious in $\mathrm{AD}$ [38].

\section{Brahmi (Bacopa monnieri)}

Brahmi (also known as Bacopa) is a bitter-tasting creeper plant found in damp and marshy areas and is commonly used in Ayurvedic medicine as a nerve tonic, diuretic, and cardiotonic and as a therapeutic agent against epilepsy, insomnia, asthma, and rheumatism [7,39]. The principal constituents of Bacopa monnieri (BM) are saponins and triterpenoid bacosaponins that include bacopasides III to $\mathrm{V}$, bacosides $\mathrm{A}$ and $\mathrm{B}$, and bacosaponins $\mathrm{A}, \mathrm{B}$, and $\mathrm{C}$. Other saponin glycosides include the jujubogenin bisdesmosides bacopasaponins D, E, and F. Other constituents include alkaloids, plant sterols, betulic acid, polyphenols, and sulfhydryl compounds that confer antioxidant activity $[7,39,40]$. Thus, BM could act by reducing divalent metals, scavenging reactive oxygen species, decreasing the formation of lipid peroxides, and inhibiting lipoxygenase activity [41]. Traditionally, BM was used to improve memory and cognitive function [42]. The BM extracts have been investigated extensively for their neuropharmacological effects and their nootropic actions [39,42-44]. In the hippocampus, BM enhances protein kinase activity that may contribute to its nootropic action [45]. BM also inhibited cholinergic degeneration and displayed a cognition-enhancing effect in a rat model of $\mathrm{AD}$ [46]. A team of researchers also reported that a standardized extract of BM reversed the cognitive deficits induced by intracerebroventricularly 
administered colchicines and ibotenic acid into the nucleus basalis magnocellularis [47]. In the same study, $\mathrm{BM}$ also reversed the (a) depletion of acetylcholine, (b) reduction in choline acetyltransferase activity, and (c) decrease in muscarinic cholinergic receptor binding in the frontal cortex and hippocampus [47]. BM extracts protected neurons from beta-amyloid-induced cell death by suppressing cellular acetylcholinesterase activity. In addition, BM extract-treated neurons expressed a lower level of reactive oxygen species, suggesting that Brahmi restrained intracellular oxidative stress [48].

An enriched phytochemical composition of BM was evaluated for short-term safety and tolerance in healthy adult volunteers. A detailed examination of clinical, hematological, biochemical, and electrocardiographic parameters did not reveal any untoward effects in any of the volunteers who received oral administration of a single capsule containing the enriched herb for 30 days (300 $\mathrm{mg}$ for the first 15 days and $450 \mathrm{mg}$ for the next 15 days) [49]. On the basis of the above-mentioned study and other clinical studies carried out to establish the efficacy of BM in memory and attention disorders, BM has now been introduced in the Indian market for treatment of memory and attention deficit disorders [50-53]. These clinical studies with Bacopa serve as a model for the way forward for other herbs to ascertain their effective dosage range, the time required to attain therapeutic levels, and their effects over a longer term of administration.

\section{Shankhpushpi (Convolvulus pluricaulis)}

Various species for Shankapushpi, including Convolvulus pluricaulis (CP), Convolvulus microphyllus, Evolvulus alsinoides, and Clitoria ternatea (CT), have been described. Shankhpushpi is a common plant in India, where the whole plant is used in various formulae as a nervine tonic for improvement of memory and cognitive function $[18,54,55]$. A wide range of secondary metabolites, including triterpenoids, flavonol glycosides, anthocyanins, and steroids, has been isolated and may be responsible for Shankhpushpi's nootropic and memory-enhancing properties in addition to other pharmacological activities [5558]. It is believed that Shankhpushpi calms the nerves by regulating the body's production of the stress hormones, adrenaline, and cortisol [58]. It is also recommended for nervous disorders such as stress, anxiety, mental fatigue, and insomnia $[7,43,55]$. The ethanolic extract of CP and its ethyl acetate and aqueous fractions significantly improved learning and memory in rats [59]. The ethanolic extract of $\mathrm{CP}$ also possesses significant antioxidant activity when tested in vitro $[18,54,59,60]$. An ethanolic extract of the whole plant, when administered to cholesterol-fed gerbils, reduced serum cholesterol, LDL cholesterol, triglycerides, and phospholipids significantly [55]. A dose-dependent enhancement of memory was observed in mice that were administered extracts of CP. Similarly, administration of CP extracts for 7 days enhanced memory in aged mice. Hippocampal regions associated with the learning and memory functions showed a dose-dependent increase in acetylcholine esterase activity in the CA1 and CA3 area with CP treatment [61]. Specifically, administration of aqueous root extract of $\mathrm{CT}$ to neonatal rat pups resulted in improved retention and spatial learning performance, indicating the memory-enhancing property of $\mathrm{CT}$. In addition, a significant increase in acetylcholine content was observed in the hippocampi of CT-treated rats in comparison with age-matched controls. Increase in acetylcholine content in the hippocampus may be the neurochemical basis for their improved learning and memory [62-64]. Young adult rats intubated with aqueous root extract of CT showed a significant increase in passive avoidance learning and retention. A significant increase in dendritic intersections, branching points, and dendritic processes arising from the soma of neurons in the amygdale region in CT-treated rats was observed in comparison with age-matched saline controls, suggesting that CT enhances memory by increasing the functional growth of neurons [65].

\section{Gotu kola (Centella asiatica)}

In the Ayurvedic system of medicine, gotu kola is one of the important rejuvenating herbs for nerve and brain cells and is believed to be capable of increasing intelligence, longevity, and memory [44,66]. Asiaticoside derivatives, including asiatic acid and asiaticoside, were shown to reduce hydrogen peroxide-induced cell death, decrease free radical concentrations, and inhibit betaamyloid cell death in vitro, suggesting a possible role for gotu kola in the treatment and prevention of $\mathrm{AD}$ and beta-amyloid toxicity [67]. Gotu kola extracts reversed the beta-amyloid pathology in the brains of PSAPP (APP/ Sw $x \mathrm{PS} \mathrm{M}_{146 \mathrm{~L}}$ ) mice and modulated the components of the oxidative stress response [66-70].

\section{Jyotishmati (Celastrus paniculatus)}

Jyotishmati is a treasured medicinal herb that is revered for its effects on the brain and has been used for centuries in Ayurveda for sharpening the memory and improving concentration and cognitive function [71]. Aqueous extracts of CP seeds have cognition-enhancing properties and antioxidant properties. CP extracts protected neuronal cells against $\mathrm{H}_{2} \mathrm{O}_{2}$-induced toxicity in part by virtue of their antioxidant properties and their ability to induce antioxidant enzymes. CP extracts also protected neuronal cells against glutamate-induced toxicity by modulating glutamate receptor function. In addition, the $\mathrm{CP}$ extracts protected neuronal cells by virtue of their 
free radical scavenging properties, reducing lipid peroxidation, and also by their ability to induce the antioxidant enzyme catalase [68,72-75]. In addition, aqueous extracts of $\mathrm{CP}$ seed have dose-dependent cholinergic activity, thereby improving memory performance [68].

\section{Jatamansi (Nardostachys jatamansi)}

Similar to its Western relative valerian, Jatamamsi is safe and balancing in its effects. The plant has a rich history of medicinal use and is highly regarded in the Ayurvedic system of medicine. The rhizomes and roots of the plant have medicinal value and, therefore, have been the focus of chemical studies. They contain a variety of sesquiterpenes and coumarins. The sedative sesquiterpene valeranone, which is also found in valerian, is a major component of the root essential oil. Other terpenoids include spirojatamol, nardostachysin, jatamols A and B, and calarenol. Jatamansi is the predominant coumarin [76-78].

Studies on its role in the CNS revealed that extracts of Nardostachys jatamansi (NJ) alleviated all of the symptoms of chronic fatigue syndrome (CFS) in rats. CFS triggered increases in lipid peroxidation, nitrite, and superoxide dismutase levels, and low catalase levels were all reversed by NJ extracts. The data indicate the powerful antioxidant property of NJ [79]. Similarly, an alcoholic extract of this plant administered to both young and aged mice significantly improved learning and memory and also reversed the amnesia induced by diazepam and scopolamine. Furthermore, it reversed aging-induced amnesia due to the natural aging of mice, suggesting that the compounds in this plant may prove to be useful in restoring memory in older individuals as well as in patients with age-associated dementia [80].

\section{Guggulu}

Guggulu is an oleogum resin exuding from the cracks and fissures in the bark or from incisions from several different plant species, including Commiphora mukul, $C$. molmol, C. abyssinica, C. Burseraceae, and C. whighitii. The oleogum resin of guggulu is a mixture of $30 \%$ to $60 \%$ water-soluble gum, $20 \%$ to $40 \%$ alcohol-soluble resins, and about $8 \%$ volatile oils. Water-soluble constituents include mucilage, sugars, and proteins. Alcohol-soluble constituents include the commiphoric acids, commiphorinic acid, and the heerabomyrrhols. Among the volatile constituents are terpenes, sesquiterpenoids, cuminic aldehyde, eugenol, and the ketone steroids Zand E-guggulsterone, and guggulsterols I, II, and III [81-83]. Guggulu also contains ferulic acids, phenols, and other non-phenolic aromatic acids that are potent scavengers of superoxide radicals and could potentially be of importance for the treatment of $\mathrm{AD}$ and other oxidative stress-related disease [84-86]. The gum resin has been used for thousands of years in the treatment of arthritis, inflammation, obesity, and disorders of lipid metabolism.

In animal models and in humans, administration of guggulipid is reported to significantly lower both serum LDL cholesterol and triglyceride levels [87-89]. Insight into the mechanism of action for the hypolipidemic activity was provided by the demonstration that guggulu is an effective antagonist of the bile acid receptor farnesoid X receptor $[87,90]$. Epidemiologic and biochemical data suggest a link between cholesterol, APP processing, and AD [91-96]. These studies indicate that there is a decreased prevalence of $\mathrm{AD}$ associated with the use of cholesterol-lowering drugs [93-96]. Decreased neuronal cholesterol levels, in turn, inhibit the betaamyloid-forming amyloidogenic pathway, possibly by removing APP from cholesterol and sphingolipid-enriched membrane microdomains. These intriguing relationships raise the hopes that cholesterol-lowering strategies may influence the progression of AD [91-96]. A recent study demonstrated that gugulipid has a significant protective effect against the streptozotocin-induced memory deficit model of dementia; the effect can be attributed to its cholesterol-lowering, antioxidant, and anti-acetylcholine esterase activity. These observations suggest gugulipid as a potential anti-dementia drug [88].

\section{Administration of Ayurvedic herbs}

The biggest challenge to drug delivery into the CNS is bypassing the blood-brain barrier (BBB) as it limits access to the CNS. For decades, the BBB has prevented the use of many therapeutic agents for treating brain-related diseases and injuries, including AD, stroke, brain tumor, head injury, and other CNS disorders. Ayurveda relies on some novel methods of administering herbs or their preparations (or both) to treat CNS disorders. However, proper studies are lacking to demonstrate whether these herbs or their components given orally or by some other means cross the BBB and reach the CNS. One novel method of herbal delivery, called 'NASYA', involves intranasal delivery of dry herbal powders or medicated oils and is a practical, non-invasive, rapid, and simple method to deliver the therapeutic agents into the CNS. The use of medicated oils, which require that the herbs be cooked in four parts oil and 16 parts water over a low flame until all of the water evaporates, ensures the transport of lipophilic and lipid-soluble molecules across the BBB membrane, where hydrophilic compounds demonstrate minimal permeation [97]. Intranasal administration offers numerous benefits for drug delivery into the CNS, and interest in this non-invasive route of administration has increased. The delivery is rapid, bypasses the $\mathrm{BBB}$, and directly targets the CNS, thereby reducing systemic exposure and side effects [98-102]. 
A second, simple method of administration involves application of the medicated oil on the body and massaging the areas with gentle or deep hand strokes. It is not clear whether this technique facilitates the transport and movement of the herbal components through the $\mathrm{BBB}$. Indirect evidence from recent studies points to such an exciting possibility. Significant brain functional activation changes together with increased cerebral blood flow were observed in participants who received a massage. Massage reduced the levels of stress-related serum cortisol, arginine vasopressin, and salivary stress protein chromogranin A with concomitant increases in circulating lymphocytes and regional cerebral blood flow [103-106]. It is tempting to speculate that, in addition to the above-mentioned hormonal changes, application of medicated oil followed by a gentle massage could relax the tight junctions between endothelial cells in the CNS vessels and facilitate the entry of solutes and other components into the CNS.

Ayurveda also relies on several transcranial oleation therapies for nervous system disorders that are nonsystemic and non-invasive. Procedures like Shirodhara (gentle dripping of the medicated oil on the forehead), Shirobasti (a special leather cap is placed over the shaved head of a patient and medicated oil is poured and retained over the head for 30 to 45 minutes), ShiroAbhyanga (medicated oil is smeared on the head followed by a gentle massage), and ShiroSeka (medicated oil is poured over the head in a continuous stream) may also influence hormonal and cerebral blood flow levels to a degree similar to that of Ayurvedic massage as mentioned above [107-110]. While scientific studies regarding the permeation of the herbal components into the CNS through transcranial oleation therapies are lacking, recent work again points to the possibility that the endothelial cells facilitate the entry of the solutes through the frontal lobe and prefrontal cortex $[109,110]$.

Aromatherapy, another popular method in the Ayurvedic system, involves the use of volatile plant materials known as essential oils for healing purposes for altering a person's mood and cognitive function. The essential oils are incorporated through steam inhalation or are topically applied to the face and arms. Aromatherapy used with massage may help to calm agitated people with dementia. There is some preliminary evidence that aromatherapy using various essential oils may have some potential for improving cognitive function, especially in patients with AD [111-113].

\section{Conclusions}

The pharmaceutical industry is facing serious challenges as the drug discovery process for neurodegenerative diseases is becoming extremely expensive, riskier, and critically inefficient. A significant shift from a single-target to a multi-target drug approach, especially for chronic and complex disease syndromes, is being witnessed. Approaches based on reverse pharmacology (from the clinic to the bedside) also offer efficient development platforms for herbal formulations. The Ayurvedic system of medicine has garnered increasing recognition in recent years with regard to diet and treatment options. Early development of Ayurvedic herbal supplements required only anecdotal or epidemiologic information (or both) without an understanding of the mode of action. The Ayurvedic medicine industry has come a long way from when it was considered unnecessary to test Ayurvedic formulations prior to use, to several randomized, double-blind, controlled studies and to the introduction of good manufacturing practice guidelines for the industry. It has taken a more rigorous scientific and quality-enhanced approach to provide 'proof of concept' and a 'mode of action'. It might be worth pointing out that, while Ayurvedic therapeutics has been prescribed for centuries for neurodegenerative diseases (including dementias), only recently have there been Western, mechanistic studies on $\mathrm{AD}$; however, these mechanistic studies point to the same mechanisms addressed by the Ayurvedic therapeutics (for example, increase in nerve growth factors and neurotrophic factors and reduction in inflammation and oxidative damage), providing strong support for herbal therapy for AD [11]. It is hoped that the strong knowledge base of Ayurveda coupled with combinatorial sciences and high-throughput screening techniques will improve the ease with which Ayurvedic products and formulations can be used in drug discovery campaigns and development process, thereby providing new functional leads for $\mathrm{AD}$ and other age-associated neurodegenerative diseases.

\section{Abbreviations \\ AD, Alzheimer's disease; BBB, blood-brain barrier; BM, Bacopa monnieri; CFS, chronic fatigue syndrome; CNS, central nervous system; CP, Convolvulus pluricaulis; CT, Clitoria ternatea; LDL, low-density lipoprotein; NJ, Nardostachys jatamansi; ppm, parts per million. \\ Competing interests \\ The authors declare that they have no competing interests. \\ Acknowledgments \\ We thank the members of the laboratory of DEB for helpful comments and discussions and Rowena Abulencia for administrative assistance. This work was supported in part by grants from the National Institutes of Health (NS33376 to DEB and RVR and AG034427-02 to DEB), the Douglas and Ellen Rosenberg Foundation (DEB), and the Stephen D. Bechtel Foundation (RVR).}

\section{Author details}

'The Buck Institute for Research on Aging, 8001 Redwood Boulevard, Novato, CA 94945, USA. ${ }^{2}$ Department of Neurology, University of California, San Francisco, CA 94143, USA.

Published: 29 June 2012 


\section{References}

1. Alzheimer's Association: 2010 Alzheimer's disease facts and figures. Alzheimers Dement 6:158-194.

2. Bredesen DE: Neurodegeneration in Alzheimer's disease: caspases and synaptic element interdependence. Mol Neurodegener 2009, 4:27.

3. Abascal K, Yarnell E: Alzheimer's disease: part 2-A botanical treatment plan. Alternative and Complementary Therapies 2004, 10:67-72.

4. Perry EK, Pickering AT, Wang WW, Houghton PJ, Perry NS: Medicinal plants and Alzheimer's disease: from ethnobotany to phytotherapy. J Pharm Pharmacol 1999, 51:527-534.

5. Howes MJ, Perry NS, Houghton PJ: Plants with traditional uses and activities, relevant to the management of Alzheimer's disease and other cognitive disorders. Phytother Res 2003, 17:1-18.

6. Kennedy DO, Wightman EL: Herbal extracts and phytochemicals: plant secondary metabolites and the enhancement of human brain function. Adv Nutr 2011, 2:32-50

7. Kumar V: Potential medicinal plants for CNS disorders: an overview. Phytother Res 2006, 20:1023-1035.

8. Manyam BV: Dementia in Ayurveda. J Altern Complement Med 1999, 5:81-88.

9. Mishra LC, Singh BB, Dagenais S: Scientific basis for the therapeutic use of Withania somnifera (ashwagandha): a review. Altern Med Rev 2000, 5:334-346.

10. Kelley BJ, Knopman DS: Alternative medicine and Alzheimer disease. Neurologist 2008, 14:299-306.

11. Wollen KA: Alzheimer's disease: the pros and cons of pharmaceutical nutritional, botanical, and stimulatory therapies, with a discussion of treatment strategies from the perspective of patients and practitioners. Altern Med Rev 2010, 15:223-244.

12. Russo A, Izzo AA, Cardile V, Borrelli F, Vanella A: Indian medicinal plants as antiradicals and DNA cleavage protectors. Phytomedicine 2001, 8:125-132.

13. Monograph. Withania somnifera. Altern Med Rev 2004, 9:211-214.

14. Auddy B, Hazra J, Mitra A, Abedon B, Ghosal S: A standardized Withania somnifera extract significantly reduces stress-related parameters in chronically stressed humans: a double-blind randomized, placebocontrolled study. J Am Nutra Assoc 2008, 11:50-56.

15. Matsuda H, Murakami T, Kishi A, Yoshikawa M: Structures of withanosides I, II, III, IV, V, VI, and VII, new withanolide glycosides, from the roots of Indian Withania somnifera DUNAL. and inhibitory activity for tachyphylaxis to clonidine in isolated guinea-pig ileum. Bioorg Med Chem 2001, 9:1499-1507.

16. Dhuley JN: Effect of ashwagandha on lipid peroxidation in stress-induced animals. J Ethnopharmacol 1998, 60:173-178.

17. Jayaprakasam B, Padmanabhan K, Nair MG: Withanamides in Withania somnifera fruit protect PC-12 cells from beta-amyloid responsible for Alzheimer's disease. Phytother Res 2010, 24:859-863.

18. Parihar MS, Hemnani T: Phenolic antioxidants attenuate hippocampal neuronal cell damage against kainic acid induced excitotoxicity. J Biosci 2003, 28:121-128.

19. Kumar S, Harris RJ, Seal CJ, Okello EJ: An aqueous extract of Withania somnifera root inhibits amyloid beta fibril formation in vitro. Phytother Res 2012, 26:113-117.

20. Tohda C, Kuboyama T, Komatsu K: Search for natural products related to regeneration of the neuronal network. Neurosignals 2005, 14:34-45.

21. Kuboyama T, Tohda C, Zhao J, Nakamura N, Hattori M, Komatsu K: Axon- or dendrite-predominant outgrowth induced by constituents from Ashwagandha. Neuroreport 2002, 13:1715-1720.

22. Schliebs R, Liebmann A, Bhattacharya SK, Kumar A, Ghosal S, Bigl V: Systemic administration of defined extracts from Withania somnifera (Indian Ginseng) and Shilajit differentially affects cholinergic but not glutamatergic and GABAergic markers in rat brain. Neurochem Int 1997 30:181-190

23. Tohda C, Kuboyama T, Komatsu K: Dendrite extension by methanol extract of Ashwagandha (roots of Withania somnifera) in SK-N-SH cells. Neuroreport 2000, 11:1981-1985

24. Kuboyama T, Tohda C, Komatsu K: Neuritic regeneration and synaptic reconstruction induced by withanolide A. Br J Pharmacol 2005, 144:961-971.

25. Aggarwal BB, Sundaram C, Malani N, Ichikawa H: Curcumin: the Indian solid gold. Adv Exp Med Biol 2007, 595:1-75

26. Shishodia S, Sethi G, Aggarwal BB: Curcumin: getting back to the roots. Ann NYAcad Sci 2005, 1056:206-217.

27. Begum AN, Jones MR, Lim GP, Morihara T, Kim P, Heath DD, Rock CL, Pruitt
MA, Yang F, Hudspeth B, Hu S, Faull KF, Teter B, Cole GM, Frautschy SA: Curcumin structure-function, bioavailability, and efficacy in models of neuroinflammation and Alzheimer's disease. J Pharmacol Exp Ther 2008, 326:196-208.

28. Chainani-Wu N: Safety and anti-inflammatory activity of curcumin: a component of tumeric (Curcuma longa). J Altern Complement Med 2003 9:161-168.

29. Ganguli M, Chandra V, Kamboh MI, Johnston JM, Dodge HH, Thelma BK, Juyal RC, Pandav R, Belle SH, DeKosky ST: Apolipoprotein E polymorphism and Alzheimer disease: The Indo-US Cross-National Dementia Study. Arch Neurol 2000, 57:824-830.

30. Breitner JC, Welsh KA, Helms MJ, Gaskell PC, Gau BA, Roses AD, Pericak-Vance MA, Saunders AM: Delayed onset of Alzheimer's disease with nonsteroidal anti-inflammatory and histamine $\mathrm{H} 2$ blocking drugs. Neurobiol Aging 1995 , 16:523-530.

31. Cole GM, Lim GP, Yang F, Teter B, Begum A, Ma Q, Harris-White ME, Frautschy SA: Prevention of Alzheimer's disease: omega-3 fatty acid and phenolic anti-oxidant interventions. Neurobiol Aging 2005, 26 Suppl 1:133-136.

32. Lim GP, Chu T, Yang F, Beech W, Frautschy SA, Cole GM: The curry spice curcumin reduces oxidative damage and amyloid pathology in an Alzheimer transgenic mouse. J Neurosci 2001, 21:8370-8377.

33. Yang F, Lim GP, Begum AN, Ubeda OJ, Simmons MR, Ambegaokar SS, Chen PP, Kayed R, Glabe CG, Frautschy SA, Cole GM: Curcumin inhibits formation of amyloid beta oligomers and fibrils, binds plaques, and reduces amyloid in vivo. J Biol Chem 2005, 280:5892-5901.

34. Butterfield D, Castegna A, Pocernich C, Drake J, Scapagnini G, Calabrese V: Nutritional approaches to combat oxidative stress in Alzheimer's disease. J Nutr Biochem 2002, 13:444

35. Toxicology and Carcinogenesis studies of Turmeric oleoresin, CAS NO. 8024-37-1, Technical Report Series, National Toxicology Program.

36. ClinicalTrials.gov homepage [http://clinicaltrials.gov/]

37. Baum L, Lam CW, Cheung SK, KwokT, Lui V, Tsoh J, Lam L, Leung V, Hui E, Ng C, Woo J, Chiu HF, Goggins WB, Zee BC, Cheng KF, Fong CY, Wong A, Mok H, Chow MS, Ho PC, Ip SP, Ho CS, Yu XW, Lai CY, Chan MH, Szeto S, Chan IH, Mok $\checkmark$ : Six-month randomized, placebo-controlled, double-blind, pilot clinical trial of curcumin in patients with Alzheimer disease. J Clin Psychopharmacol 2008, 28:110-113.

38. Belkacemi A, Doggui S, Dao L, Ramassamy C: Challenges associated with curcumin therapy in Alzheimer disease. Expert Rev Mol Med 2011, 13:e34

39. Bacopa monniera. Monograph. Altern Med Rev 2004, 9:79-85.

40. Russo A, Borrelli F: Bacopa monniera, a reputed nootropic plant: an overview. Phytomedicine 2005, 12:305-317.

41. Dhanasekaran M, Tharakan B, Holcomb LA, Hitt AR, Young KA, Manyam BV Neuroprotective mechanisms of ayurvedic antidementia botanical Bacopa monniera. Phytother Res 2007, 21:965-969.

42. Stough C, Downey LA, Lloyd J, Silber B, Redman S, Hutchison C, Wesnes K, Nathan PJ: Examining the nootropic effects of a special extract of Bacopa monniera on human cognitive functioning: 90 day double-blind placebocontrolled randomized trial. Phytother Res 2008, 22:1629-1634.

43. Singh RH, Narsimhamurthy K, Singh G: Neuronutrient impact of Ayurvedic Rasayana therapy in brain aging. Biogerontology 2008, 9:369-374.

44. Shinomol GK, Muralidhara, Bharath MM: Exploring the role of 'Brahmi' (Bocopa monnieri and Centella asiatica) in brain function and therapy. Recent Pat Endocr Metab Immune Drug Discov 2011, 5:33-49.

45. Singh HK, Dhawan BN: Effect of Bacopa monniera Linn. (brahmi) extract on avoidance responses in rat. J Ethnopharmacol 1982, 5:205-214.

46. Uabundit N, Wattanathorn J, Mucimapura S, Ingkaninan K: Cognitive enhancement and neuroprotective effects of Bacopa monnieri in Alzheimer's disease model. J Ethnopharmacol 2010, 127:26-31.

47. Bhattacharya SK, Bhattacharya A, Kumar A, Ghosal S: Antioxidant activity of Bacopa monniera in rat frontal cortex, striatum and hippocampus. Phytother Res 2000, 14:174-179.

48. Limpeanchob N, Jaipan S, Rattanakaruna S, Phrompittayarat W, Ingkaninan K: Neuroprotective effect of Bacopa monnieri on beta-amyloid-induced cell death in primary cortical culture. J Ethnopharmacol 2008, 120:112-117.

49. Pravina K, Ravindra KR, Goudar KS, Vinod DR, Joshua AJ, Wasim P, Venkateshwarlu K, Saxena VS, Amit A: Safety evaluation of BacoMind in healthy volunteers: a phase I study. Phytomedicine 2007, 14:301-308.

50. Roodenrys S, Booth D, Bulzomi S, Phipps A, Micallef C, Smoker J: Chronic effects of Brahmi (Bacopa monnieri) on human memory. Neuropsychopharmacology 2002, 27:279-281. 
51. Nathan PJ, Clarke J, Lloyd J, Hutchison CW, Downey L, Stough C: The acute effects of an extract of Bacopa monniera (Brahmi) on cognitive function in healthy normal subjects. Hum Psychopharmacol 2001, 16:345-351.

52. Stough C, Lloyd J, Clarke J, Downey LA, Hutchison CW, Rodgers T, Nathan PJ: The chronic effects of an extract of Bacopa monniera (Brahmi) on cognitive function in healthy human subjects. Psychopharmacology (Berl) 2001, 156:481-484

53. Shukia B, Khanna NK, Godhwani JL: Effect of Brahmi Rasayan on the central nervous system. J Ethnopharmacol 1987, 21:65-74.

54. Bihaqi SW, Sharma M, Singh AP, Tiwari M: Neuroprotective role of Convolvulus pluricaulis on aluminium induced neurotoxicity in rat brain. J Ethnopharmacol 2009, 124:409-415.

55. Malik J, Karan M, Vasisht K: Nootropic, anxiolytic and CNS-depressant studies on different plant sources of shankhpushpi. Pharm Biol 2011, 49:1234-1242

56. Mukherjee PK, Kumar V, Kumar NS, Heinrich M: The Ayurvedic medicine Clitoria ternatea--from traditional use to scientific assessment. JEthnopharmacol 2008, 120:291-301.

57. Jain NN, Ohal CC, Shroff SK, Bhutada RH, Somani RS, Kasture VS, Kasture SB: Clitoria ternatea and the CNS. Pharmacol Biochem Behav 2003, 75:529-536.

58. Sethiya NK, Nahata A, Mishra SH, Dixit VK: An update on Shankhpushpi, a cognition-boosting Ayurvedic medicine. Zhong Xi Yi Jie He Xue Bao 2009, 7:1001-1022.

59. Nahata A, Patil UK, Dixit VK: Effect of Convulvulus pluricaulis Choisy. on learning behaviour and memory enhancement activity in rodents. Nat Prod Res 2008, 22:1472-1482.

60. Nahata A, Patil UK, Dixit VK: Effect of Evolvulus alsinoides Linn. on learning behavior and memory enhancement activity in rodents. Phytother Res 2010, 24:486-493.

61. Sharma K, Bhatnagar M, Kulkarni SK: Effect of Convolvulus pluricaulis Choisy and Asparagus racemosus Willd on learning and memory in young and old mice: a comparative evaluation. Indian J Exp Biol 2010, 48:479-485.

62. Rai KS, Murthy KD, Karanth KS, Nalini K, Rao MS, Srinivasan KK: Clitoria ternatea root extract enhances acetylcholine content in rat hippocampus. Fitoterapia 2002, 73:685-689.

63. Rai KS, Murthy KD, Karanth KS, Rao MS: Clitoria ternatea (Linn) root extract treatment during growth spurt period enhances learning and memory in rats. Indian J Physiol Pharmacol 2001, 45:305-313.

64. Taranalli AD, Cheeramkuzhy TC: Influence of Clitoria ternatea extracts on memory and central cholinergic activity in rats. Pharm Biol 2000, 38:51-56.

65. Rai KS, Murthy KD, Rao MS, Karanth KS: Altered dendritic arborization of amygdala neurons in young adult rats orally intubated with Clitorea ternatea aqueous root extract. Phytother Res 2005, 19:592-598.

66. Cervenka F, Jahodar L: [Plant metabolites as nootropics and cognitives]. Ceska Slov Farm 2006, 55:219-229. Article in Czech.

67. Dhanasekaran M, Holcomb LA, Hitt AR, Tharakan B, Porter JW, Young KA, Manyam BV: Centella asiatica extract selectively decreases amyloid beta levels in hippocampus of Alzheimer's disease animal model. Phytother Res 2009, 23:14-19.

68. da Rocha MD, Viegas FP, Campos HC, Nicastro PC, Fossaluzza PC, Fraga CA, Barreiro EJ, Viegas C Jr: The role of natural products in the discovery of new drug candidates for the treatment of neurodegenerative disorders II: Alzheimer's disease. CNS Neurol Disord Drug Targets 2011, 10:251-270.

69. Veerendra Kumar MH, Gupta YK: Effect of Centella asiatica on cognition and oxidative stress in an intracerebroventricular streptozotocin model of Alzheimer's disease in rats. Clin Exp Pharmacol Physiol 2003, 30:336-342.

70. Xu Y, Cao Z, Khan I, Luo Y: Gotu Kola (Centella asiatica) extract enhances phosphorylation of cyclic AMP response element binding protein in neuroblastoma cells expressing amyloid beta peptide. J Alzheimers Dis 2008, 13:341-349.

71. Bhanumathy M, Harish MS, Shivaprasad HN, Sushma G: Nootropic activity of Celastrus paniculatus seed. Pharm Biol 2010, 48:324-327.

72. Godkar P, Gordon RK, Ravindran A, Doctor BP: Celastrus paniculatus seed water soluble extracts protect cultured rat forebrain neuronal cells from hydrogen peroxide-induced oxidative injury. Fitoterapia 2003, 74:658-669

73. Godkar PB, Gordon RK, Ravindran A, Doctor BP: Celastrus paniculatus seed water soluble extracts protect against glutamate toxicity in neuronal cultures from rat forebrain. J Ethnopharmacol 2004, 93:213-219.

74. Godkar PB, Gordon RK, Ravindran A, Doctor BP: Celastrus paniculatus seed oil and organic extracts attenuate hydrogen peroxide- and glutamateinduced injury in embryonic rat forebrain neuronal cells. Phytomedicine
2006, 13:29-36

75. Kumar MH, Gupta YK: Antioxidant property of Celastrus paniculatus willd.: a possible mechanism in enhancing cognition. Phytomedicine 2002, 9:302-311.

76. Chatterjee A, Basak B, Saha M, Dutta U, Mukhopadhyay C, Banerji J, Konda Y, Harigaya Y: Structure and stereochemistry of nardostachysin, a new terpenoid ester constituent of the rhizomes of Nardostachys jatamansi. J Nat Prod 2000, 63:1531-1533.

77. Bagchi A, Oshima Y, Hikino H: Jatamols A and B: Sesquiterpenoids of Nardostachys jatamansi Roots1. Planta Med 1991, 57:282-283.

78. Bagchi A, Oshima Y, Hikino H: Neolignans and Lignans of Nardostachys jatamansi Roots1. Planta Med 1991, 57:96-97.

79. Lyle N, Gomes A, Sur T, Munshi S, Paul S, Chatterjee S, Bhattacharyya D: The role of antioxidant properties of Nardostachys jatamansi in alleviation of the symptoms of the chronic fatigue syndrome. Behav Brain Res 2009, 202:285-290.

80. Joshi H, Parle M: Nardostachys jatamansi improves learning and memory in mice. J Med Food 2006, 9:113-118.

81. Das Gupta R: A new hypolipidaemic agent (gugulipid). J Assoc Physicians India 1990, 38:186.

82. Gupta RD: Gugulipid: pro-lipaemic effect. J Assoc Physicians India 1990, 38:598.

83. Urizar NL, Moore DD: GUGULIPID: a natural cholesterol-lowering agent. Annu Rev Nutr 2003, 23:303-313.

84. Perluigi M, Joshi G, Sultana R, Calabrese V, De Marco C, Coccia R, Cini C, Butterfield DA: In vivo protective effects of ferulic acid ethyl ester against amyloid-beta peptide 1-42-induced oxidative stress. J Neurosci Res 2006, 84:418-426.

85. Scapagnini G, Butterfield DA, Colombrita C, Sultana R, Pascale A, Calabrese V: Ethyl ferulate, a lipophilic polyphenol, induces $\mathrm{HO}-1$ and protects rat neurons against oxidative stress. Antioxid Redox Signal 2004, 6:811-818.

86. Sultana R, Ravagna A, Mohmmad-Abdul H, Calabrese V, Butterfield DA: Ferulic acid ethyl ester protects neurons against amyloid beta- peptide(142)-induced oxidative stress and neurotoxicity: relationship to antioxidant activity. J Neurochem 2005, 92:749-758.

87. Cui J, Huang L, Zhao A, Lew JL, Yu J, Sahoo S, Meinke PT, Royo I, Pelaez F, Wright SD: Guggulsterone is a farnesoid $X$ receptor antagonist in coactivator association assays but acts to enhance transcription of bile salt export pump. J Biol Chem 2003, 278:10214-10220

88. Saxena G, Singh SP, Pal R, Singh S, Pratap R, Nath C: Gugulipid, an extract of Commiphora whighitii with lipid-lowering properties, has protective effects against streptozotocin-induced memory deficits in mice. Pharmacol Biochem Behav 2007, 86:797-805

89. Szapary PO, Wolfe ML, Bloedon LT, Cucchiara AJ, DerMarderosian AH, Cirigliano MD, Rader DJ: Guggulipid for the treatment of hypercholesterolemia: a randomized controlled trial. JAMA 2003, 290:765-772.

90. Urizar NL, Liverman AB, Dodds DT, Silva FV, Ordentlich P, Yan Y, Gonzalez FJ, Heyman RA, Mangelsdorf DJ, Moore DD: A natural product that lowers cholesterol as an antagonist ligand for FXR. Science 2002, 296:1703-1706.

91. Eckert GP, Wood WG, Muller WE: Statins: drugs for Alzheimer's disease? J Neural Transm 2005, 112:1057-1071.

92. Kirsch C, Eckert GP, Koudinov AR, Muller WE: Brain cholesterol, statins and Alzheimer's disease. Pharmacopsychiatry 2003, 36 Suppl 2:S113-119.

93. Vestergaard M, Hamada T, Morita M, Takagi M: Cholesterol, lipids, amyloid beta, and Alzheimer's. Curr Alzheimer Res 2010, 7:262-270.

94. Morley JE, Banks WA: Lipids and cognition. J Alzheimers Dis 2010, 20:737-747.

95. Liu JP, Tang Y, Zhou S, Toh BH, McLean C, Li H: Cholesterol involvement in the pathogenesis of neurodegenerative diseases. Mol Cell Neurosci 2010, 43:33-42.

96. Harris JR, Milton NG: Cholesterol in Alzheimer's disease and other amyloidogenic disorders. Subcell Biochem 2010, 51:47-75.

97. Frawley D, Lad V: The Yoga of Herbs: An Ayurvedic Guide to Herbal Medicine Twin Lakes, WI: Lotus Press; 1986

98. Pires A, Fortuna A, Alves G, Falcao A: Intranasal drug delivery: how, why and what for? J Pharm Pharm Sci 2009, 12:288-311.

99. Turker S, Onur E, Ozer Y: Nasal route and drug delivery systems. Pharm World Sci 2004, 26:137-142.

100. Illum L: Nasal drug delivery--possibilities, problems and solutions. J Control Release 2003, 87:187-198.

101. Craft S, Baker LD, Montine TJ, Minoshima S, Watson GS, Claxton A, Arbuckle M, 
Callaghan M, Tsai E, Plymate SR, Green PS, Leverenz J, Cross D, Gerton B: Intranasal insulin therapy for Alzheimer disease and amnestic mild cognitive impairment: a pilot clinical trial. Arch Neurol 2012, 69:29-38.

102. Dhuria SV, Hanson LR, Frey WH 2nd: Intranasal delivery to the central nervous system: mechanisms and experimental considerations. J Pharm Sci 2010, 99:1654-1673.

103. Rapaport MH, Schettler P, Bresee C: A preliminary study of the effects of a single session of Swedish massage on hypothalamic-pituitary-adrenal and immune function in normal individuals. J Altern Complement Med $2010 \mathrm{Sep}$ 1. [Epub ahead of print].

104. Buckle J, Newberg A, Wintering N, Hutton E, Lido C, Farrar JT: Measurement of regional cerebral blood flow associated with the $M$ technique-light massage therapy: a case series and longitudinal study using SPECT. J Altern Complement Med 2008, 14:903-910.

105. Keir ST: Effect of massage therapy on stress levels and quality of life in brain tumor patients--observations from a pilot study. Support Care Cancer 2011, 19:711-715.

106. Ouchi Y, Kanno T, Okada H, Yoshikawa E, Shinke T, Nagasawa S, Minoda K, Doi $\mathrm{H}$ : Changes in cerebral blood flow under the prone condition with and without massage. Neurosci Lett 2006, 407:131-135.

107. Pathirana W, Abhayawardhana P, Kariyawasam H, Ratnasooriya WD: Transcranial route of brain targeted delivery of methadone in oil. Indian J Pharm Sci 2009, 71:264-269.
108. Saxena VS, Nadkarni W: Nonpharmacological treatment of epilepsy. Ann Indian Acad Neurol 2011, 14:148-152.

109. Uebaba K, Xu FH, Ogawa H, Tatsuse T, Wang BH, Hisajima T, Venkatraman S: Psychoneuroimmunologic effects of Ayurvedic oil-dripping treatment. J Altern Complement Med 2008, 14:1189-1198.

110. Xu F, Uebaba K, Ogawa H, Tatsuse T, Wang BH, Hisajima T, Venkatraman S: Pharmaco-physio-psychologic effect of Ayurvedic oil-dripping treatment using an essential oil from Lavendula angustifolia. J Altern Complement Med 2008, 14:947-956.

111. Mantle F: The role of alternative medicine in treating postnatal depression. Complement Ther Nurs Midwifery 2002, 8:197-203.

112. Jimbo D, Kimura Y, Taniguchi M, Inoue M, Urakami K: Effect of aromatherapy on patients with Alzheimer's disease. Psychogeriatrics 2009, 9:173-179.

113. Ballard CG, Gauthier S, Cummings JL, Brodaty H, Grossberg GT, Robert P, Lyketsos CG: Management of agitation and aggression associated with Alzheimer disease. Nat Rev Neurol 2009, 5:245-255.

doi:10.1186/alzrt125

Cite this article as: Rao RV, et al:: Ayurvedic medicinal plants for Alzheimer's disease: a review. Alzheimer's Research \& Therapy 2012, 4:22. 